\title{
Copper and selenium supplementation in the diet of Brangus steers on the nutritional characteristics of meat
}

\author{
Arlindo Saran Netto ${ }^{1}$, Marcus Antonio Zanetti ${ }^{1}$, Gustavo Ribeiro Del Claro ${ }^{1}$, Flávio Garcia \\ Vilela ${ }^{2}$, Mariza Pires de Melo ${ }^{3}$, Lísia Bertonha Correa ${ }^{1}$, Silvana Marina Piccoli Pugine ${ }^{3}$ \\ ${ }^{1}$ Departamento de Zootecnia - Faculdade de Zootecnia e Engenharia de Alimentos - Universidade de São Paulo. Av. Duque de Caxias Norte, 225, \\ CEP: 13630-000, Pirassununga - São Paulo - Brazil. \\ 2 Departamento de Nutrição e Produção Animal - Faculdade de Medicina Veterinária e Zootecnia - Universidade de São Paulo. Av. Duque de \\ Caxias Norte, 225, CEP: 13630-000, Pirassununga - São Paulo - Brazil. \\ ${ }^{3}$ Departamento de Ciências Básicas - Faculdade de Zootecnia e Engenharia de Alimentos - Universidade de São Paulo. Av. Duque de Caxias \\ Norte, 225, CEP: 13630-000, Pirassununga - São Paulo - Brazil.
}

\begin{abstract}
Twenty-eight Brangus cattle were used to determine the effect of copper and selenium supplementation on the carcass characteristics, fatty acid composition of the longissimus dorsi muscle and on the copper and selenium concentrations in the liver. The treatments were: no supplementation of copper or selenium; $2 \mathrm{mg} \mathrm{Se} / \mathrm{kg} \mathrm{DM}$ as sodium selenite; $40 \mathrm{mg} \mathrm{Cu} / \mathrm{kg}$ $\mathrm{DM}$ as copper sulfate; and $2 \mathrm{mg} \mathrm{Se} / \mathrm{kg} \mathrm{DM}$ as sodium selenite and $40 \mathrm{mg} \mathrm{Cu} / \mathrm{kg} \mathrm{DM}$ as copper sulfate. The fat thickness, rib eye area and fatty acid composition of the longissimus dorsi muscle were not affected by treatments. There was no effect on carcass yield and cooling loss with the supplementation of copper, selenium or selenium $\times$ copper in the levels studied. For the ether extract concentration in the longissimus dorsi muscle, no differences were found according to the treatments with selenium, copper or selenium $\times$ copper. The treatments with selenium and selenium $\times$ copper showed higher selenium concentrations in the liver than the control and copper treatments. For the copper concentration in the liver, the copper and selenium $\times$ copper treatments showed higher values than the control and selenium treatments. Despite the little effect on the meat composition, the results of this experiment demonstrate no interaction between selenium and copper in the levels studied.
\end{abstract}

Key Words: cattle, concentrations, fatty acids, minerals

\section{Introduction}

Adult animals usually absorb $5-10 \%$ of copper in the diet, while young ones can absorb between 15 and $30 \%$ of it. In ruminants, according to McDowell (1992), about 1-3\% of copper are absorbed. Copper absorption occurs in all segments of the gastrointestinal tract. The small intestine has the highest absorption; however, the human stomach and the large intestine of sheep present considerable absorption (O’Dell \& Sunde, 1997).

Most of the copper present in the plasma of mammals is in the form of ceruloplasmin, which is the specific carrier, exporting copper from liver to target organs (McDowell, 1992).

The liver is the central organ of copper metabolism, and its concentration in this organ reflects the level of copper ingested by the organism (McDowell, 1992). The copper concentration in the liver, in most of the mammals, increases with the age; however, cattle are an exception, whose copper concentration in the liver varies very little with the animal age.
The absorption of selenium in ruminants occurs mainly in the duodenum, while in pigs it occurs in the ileum, cecum and colon. The absorption in ruminants is lower than that in non-ruminants, since the selenite can be reduced to insoluble compounds in the rumen (McDowell, 1992). The selenium requirement for beef cattle is $0.1 \mathrm{mg} / \mathrm{kg} \mathrm{DM}$ and the estimated maximum concentration to avoid toxicity problems is $2 \mathrm{mg} / \mathrm{kg}$ dry matter (DM) (NRC, 2000), but the NRC (2005) has recently increased this level to $5 \mathrm{mg} / \mathrm{kg}$.

The interaction between copper and selenium has been reported in experiments conducted with ruminants and non-ruminants. Adult sheep that received high concentrations of copper sulfate for a long period had increased selenium in the liver. However, no differences in excretion and Se retention were found when using 0 to $10 \mathrm{mg} / \mathrm{kg}$ of copper supplementation. Selenium supplementation to sheep with copper deficiency results in significant increase of copper concentration in the liver (McChowell \& Gawthorhe, 1985).

Some experiments have suggested that the copper supplementation may affect the lipid metabolism in 
ruminants (Engle \& Spears, 2000; Engle et al., 2000a; Engle et al., 2000b; Engle et al., 2000c; Engle \& Spears, 2001). The mechanism by which copper affects the fatty acid profile is not clear, but it includes effects on denaturation, esterification and mobilization of triglycerides. Copper has a high reduction potential and in the rumen it may reduce some reduction equivalents in the form of NAPDH and $\mathrm{NADH}$, interfering with the microbial biohydrogenation of unsaturated fatty acids.

Thus, the objective of this study was to evaluate the effect of selenium, copper and selenium $\times$ copper supplementation on steers regarding the carcass parameters and nutritional characteristics of meat.

\section{Material and Methods}

The experiment was carried out at Faculdade de Zootecnia e Engenharia de Alimentos at Universidade de São Paulo, campus Pirassununga, in São Paulo, Brazil, for a period of 131 days between the months of December 2005 and April 2006. Twenty-eight male uncastrated Brangus cattle with initial weight of $395 \pm 15 \mathrm{~kg}$ were placed in 28 stalls, for the experiment.

Initially, the animals were adapted to diet and the experimental feedlot for 30 days. After the adaptation period, the experiment itself was conducted and lasted 101 days.

The animals received a diet containing high proportion of concentrate $(75 \%)$, with corn as the source of forage (Table 1). For the calculation of nutritional requirements, the Cornell Net Carbohydrate and Protein System (CNCPS) was used (Fox et al., 1992).

Table 1 - Percentage and chemical composition of the basal diet, based on the total dry matter (DM)

\begin{tabular}{lc}
\hline Ingredients & $(\mathrm{g} / \mathrm{kg} \mathrm{DM})$ \\
\hline Corn silage & 250 \\
Ground corn & 642.1 \\
Extruded soybean & 78.68 \\
Urea & 9.64 \\
Sodium bicarbonate & 3.03 \\
White salt & 2.81 \\
Limestone & 6.02 \\
Rumensin & 0.21 \\
Mineral salt & 7.54 \\
Chemical composition & $(\mathrm{g} / \mathrm{kg})$ \\
Crude protein & 129.0 \\
Ether extract & 42.1 \\
Neutral detergent fiber & 183.4 \\
Acid detergent fiber & 160.5 \\
& $(\mathrm{mg} / \mathrm{kg})$ \\
Copper & 5.801 \\
Selenium & 0.060 \\
\hline
\end{tabular}

The 28 animals were distributed into four groups, with seven animals per treatment: basal diet without additional supplementation of copper and selenium; basal diet with $2 \mathrm{mg}$ selenium $/ \mathrm{kg}$ of dry matter in the form of sodium selenite; basal diet supplemented with $40 \mathrm{mg}$ copper $/ \mathrm{kg}$ of dry matter in the form of copper sulphate; and basal diet supplemented with $40 \mathrm{mg}$ copper $/ \mathrm{kg}$ of dry matter in the form of copper sulphate, and $2 \mathrm{mg}$ selenium $/ \mathrm{kg}$ of dry matter in the form of sodium selenite.

After the fasting period of 16 hours, the animals were slaughtered at the Slaughterhouse - Administrative Campus of Pirassununga, as routine procedure. The animals were stunned by cerebral concussion and killed by bleeding in the jugular vein in the vertical position, followed by skinning, evisceration, inspection, sawing of carcasses in half, dissecation and evaluation of hot carcass weight.

Also on the boning day, the left half carcasses were sawn between the 12th and 13th ribs for measurement of rib eye area and fat thickness with the aid of a reticulate grid to scale in $\mathrm{cm}^{2}$, especially for this purpose.

To determinine the ether extract and fatty acid profile, four samples of approximately $2.5 \mathrm{~cm}$ thickness of the longissimus dorsi (LD) muscle were collected. Samples were obtained from the right liver lobe of each animal for analysis of copper and selenium.

The rib eye area was determined by section between the 12th and 13th ribs of the left half carcass, exposing a cross section of the longissimus dorsi (LD) muscle and determining the area with the aid of a checkered rule (grid). The results were expressed in $\mathrm{cm}^{2}$.

The fat thickness was directly measured in the same section of longissimus dorsi (LD) muscle used for determining the rib eye area with the aid of a caliper rule and the results were expressed in millimeters.

The determinations of dry matter, ash, crude protein, ether extract and acid detergent fiber of the diets followed the recommendations of the AOAC (1996).

The copper in the liver was analyzed by atomic absorption spectrophotometry. Analyses of selenium were performed after nitric-perchloric wet digestion and fluorimetric reading (Olson et al., 1975). For the analysis of tissues collected, liver and muscle, they were defrosted and had a separate fragment, always removed from the same region, washed in distilled deionized water, dried in a disposable absorbent paper and weighed on a precision scale.

The fraction of ether extract in the muscle was determined by soxhlet extractor with the solvent chloroform, after previous lyophilization of the samples. Two grams of previously homogenized sample were used. 
The fatty acid composition of the longissimus dorsi muscle was analyzed by high resolution gas chromatography, according to methodology described by Perez et al. (2002) and conducted at the Laboratory of Cell Physiology, Departamento de Fisiologia e Biofísica of Instituto de Ciências Biológicas - USP.

The statistical design was completely randomized with a $2 \times 2$ factorial arrangement and seven repetitions per treatment. Data were analyzed by the statistical package SAS (Statistical Analysis System, version 9.1), using command PROC MIXED at 5\% significance level.

\section{Results and Discussion}

The treatments selenium and selenium $\times$ copper showed higher concentration of selenium $(\mathrm{P}<0.05)$ in the liver than the control and copper treatments (Table 2). For copper concentration, the copper and selenium $\times$ copper treatments showed higher values than the control and selenium treatments $(\mathrm{P}<0.05)$.

The selenium concentration in the liver of cattle increased with the selenium supplementation in the diet, in both supplementation in isolation and combined with copper. The diets supplemented with selenium showed greater accumulation of selenium in the liver than diets without selenium supplementation. Selenium is distributed by the whole organism, and most of the selenium absorbed from sodium selenite is accumulated in the liver (Herdt et al., 2000). According to Valk \& Horstra (2000), the concentration of selenium in the liver provides accurate indication of the recent selenium intake, which explains the higher values found in the treatments with higher dietary selenium. Selenium concentrations in the liver of the experimental animals ranged between 7.26 and 21.45 $\mathrm{mg} / \mathrm{kg}$ of dry matter. According to Underwood \& Suttle (1999), disturbances from selenium intoxication depend on the continued consumption until reaching saturation values in the tissues. For the liver, according to the authors, the saturation value can range from 20 to $30 \mathrm{mg} / \mathrm{kg}$ of DM. Thus, even in treatments with a high level of selenium, the high levels found in liver were not toxic, since the values of dietary toxicity recommended by the NRC (2000) were respected.

The selenium treatment did not show difference $(\mathrm{P}>0.05)$ compared with the selenium $\times$ copper treatment for selenium concentration in the liver. The copper treatment also showed no changes in hepatic levels of selenium compared with control. These two results denote no interaction between selenium and copper in the levels studied. McChowell \& Gawthorhe (1985) reported that the supplementation with high concentrations of copper sulphate resulted in increased selenium in the liver. Van Ryssen et al. (1998) also reported that increase in dietary copper resulted in significant increase of selenium in the liver. According to Deol et al. (1994), high levels of copper increase the levels of hepatic selenium, which occurs due to indirect interaction, result of the damage caused in the liver by high levels of copper. In this study, the level of $40 \mathrm{mg} / \mathrm{kg}$, although superior to the level recommended by the NRC (2000), is not considered toxic, which explains the lack of interaction with the hepatic selenium levels.

The hepatic copper concentration increased with the increasing dietary levels of this mineral. The copper, after being absorbed, is transported to the liver, which is the main organ for storage. The hepatic concentration reflects the level of copper ingested by the organism (McDowell, 1992), which explains the results obtained in this study; in other words, higher concentration of hepatic copper in the copper and selenium $\times$ copper treatments. In these treatments, the average concentrations of copper were 748.37 and $696.48 \mathrm{mg} / \mathrm{kg}$ of DM and although high, no animal showed signs of copper intoxication, and they showed normal anatomy and weight of kidney and liver.

When comparing the selenium treatment with the control, no significant differences were observed in hepatic copper content. The selenium $\times$ copper treatment also did not differ significantly from the copper treatment, which shows no interaction in the levels studied. Brisola (2000) found decrease of serum copper with selenium supplementation; however, there was no effect on hepatic copper, as in this experiment. McChowell \& Gawthorne (1985) reported that supplementation with selenium for

Table 2 - Concentration of selenium and copper in $\mathrm{mg}$ per $\mathrm{kg}$ of liver (dry basis) of cattle receiving different treatments

\begin{tabular}{|c|c|c|c|c|c|c|c|c|c|}
\hline \multirow{2}{*}{ Variable } & \multicolumn{4}{|c|}{ Treatments } & \multirow{2}{*}{ Means } & \multirow{2}{*}{$\mathrm{SE}$} & \multicolumn{3}{|c|}{$\mathrm{P}$ values } \\
\hline & $\mathrm{C}$ & $\mathrm{Se}$ & $\mathrm{Cu}$ & $\mathrm{Se} \times \mathrm{Cu}$ & & & $\mathrm{Se}$ & $\mathrm{Cu}$ & $\mathrm{Se} \times \mathrm{Cu}$ \\
\hline Selenium in the liver & 9.523 & 16.762 & 8.576 & 17.691 & 13.454 & 0.913 & 0.0001 & 0.992 & 0.288 \\
\hline Copper in the liver & 383.78 & 295.39 & 748.37 & 696.48 & 528.307 & 49.879 & 0.301 & 0.0001 & 0.785 \\
\hline
\end{tabular}

SE - standard error; C - control diet (without supplementation of copper and selenium); Se - supplementation of $2 \mathrm{mg}$ selenium/kg of dry matter in the form of sodium selenite; $\mathrm{Cu}$ - supplementation of $40 \mathrm{mg}$ copper/ $\mathrm{kg}$ of dry matter in the form of copper sulphate; $\mathrm{Se} \times \mathrm{Cu}$ - supplementation of $2 \mathrm{mg}$ selenium/kg of dry matter in the form of sodium selenite and $40 \mathrm{mg}$ copper $/ \mathrm{kg}$ of dry matter in the form of copper sulphate. 
growing sheep with copper deficiency results in increased hepatic copper; however, this effect is not found in sheep with an appropriate status of this mineral. In adult sheep, the authors reported that selenium supplementation did not alter the status of copper. If this explanation is valid for cattle, it can explain the results obtained in this study, since even the animals of the control treatment were not copper-deficient and the animals used in this study were at the finishing phase.

There was no significant effect on carcass yield or cooling loss with the supplementation of copper, selenium or selenium $\times$ copper in the levels studied (Table 3 ).

Engle et al. (2000a) found reduction in the carcass weight of animals supplemented with $40 \mathrm{mg}$ copper $/ \mathrm{kg}$ of DM; however, the authors also found decrease of fat thickness in the longissimus dorsi muscle, which may be the explanation for this result. Engle \& Spears (2000) found no change in cooling loss or hot carcass weight with supplementation of $20 \mathrm{mg}$ copper/ $\mathrm{kg}$ of DM; however, these authors also found no reduction in fat thickness. Regarding the treatments with selenium, as the results found in present study, some authors like Lawler et al. (2004) and Mahan et al. (1999) supplemented selenium and found no change in hot carcass weight in cattle and swine, respectively.

This study found no reduction in fat thickness in the longissimus dorsi muscle, which explains why there was no change in either carcass yield or cooling loss.
There was no effect of the copper, selenium, or selenium $\times$ copper supplementation on fat thickness and rib eye area (Table 4), both at the height of the 5th and 12th ribs. However, the selenium $\times$ copper treatment showed 35\% reduction in fat thickness compared with the control. If the data variation was lower, a significant difference $(\mathrm{P}<0.05)$ would probably be found. For the concentration of ether extract in the longissimus dorsi muscle, no differences $(\mathrm{P}>0.05)$ were found in relation to the treatments with selenium, copper or selenium $\times$ copper (Figure 1).

Some studies reported decrease in fat thickness and increase in rib eye area with copper supplementation at $40 \mathrm{mg} / \mathrm{kg}$ of DM (Engle et al., 2000a; Engle \& Spears, 2000; Ward \& Spears, 1997). The explanation of the authors is based on the experiment conducted by Konjufca et al. (1997) with birds, where decreased activity of the enzyme fatty acid synthase was found with elevated levels of copper. Thus, elevated levels of copper reduce this enzyme activity and consequently the synthesis of fat, decreasing the fat thickness and also the concentration of ether extract in meat. This study did not measure the enzyme activity of fatty acid synthase; however, in the experiment of Konjufca et al. (1997) the levels of copper used were much higher than those used in this study ( $180 \mathrm{mg} / \mathrm{kg}$ of dry matter), which may have justified the results of this study for isolated supplementation of copper and selenium. However, the selenium $\times$ copper treatment the levels used were possibly

Table 3 - Carcass yield of cattle receiving control diet, supplemented with selenium, copper or selenium $\times$ copper

\begin{tabular}{|c|c|c|c|c|c|c|c|c|c|}
\hline \multirow{2}{*}{ Variable } & \multicolumn{4}{|c|}{ Treatments } & \multirow{2}{*}{ Means } & \multirow{2}{*}{$\mathrm{SE}$} & \multicolumn{3}{|c|}{$\mathrm{P}$ values } \\
\hline & $\mathrm{C}$ & $\mathrm{Se}$ & $\mathrm{Cu}$ & $\mathrm{Se} \times \mathrm{Cu}$ & & & $\mathrm{Se}$ & $\mathrm{Cu}$ & $\mathrm{Se} \times \mathrm{Cu}$ \\
\hline $\mathrm{HCY}$ & 58.25 & 57.91 & 58.62 & 58.69 & 58.383 & 0.304 & 0.334 & 0.776 & 0.691 \\
\hline $\mathrm{CCY}$ & 57.36 & 57.10 & 57.75 & 57.69 & 57.504 & 0.293 & 0.443 & 0.803 & 0.872 \\
\hline CL & 1.52 & 1.23 & 1.49 & 1.70 & 1.502 & 0.095 & 0.259 & 0.815 & 0.187 \\
\hline
\end{tabular}

SE - standard error; C - control diet (without supplementation of copper and selenium); Se - supplementation of $2 \mathrm{mg}$ selenium/kg of dry matter in the form of sodium selenite; $\mathrm{Cu}$ - supplementation of $40 \mathrm{mg}$ copper $/ \mathrm{kg}$ of dry matter in the form of copper sulphate; Se $\times \mathrm{Cu}$ - supplementation of $2 \mathrm{mg}$ selenium $/ \mathrm{kg}$ of dry matter in the form of sodium selenite and $40 \mathrm{mg}$ copper/kg of dry matter in the form of copper sulphate; HCY - hot carcass yield; CCY - cold carcass yield; CL - cooling loss.

Table 4 - Subcutaneous fat thickness and rib eye area of the longissimus dorsi muscle of cattle according to treatments

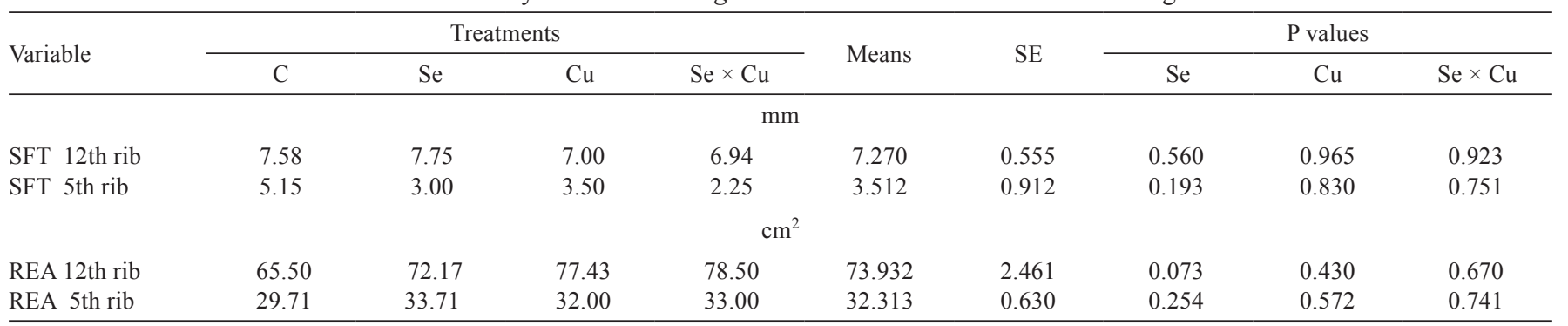

SE - standard error; C - control diet (without supplementation of copper and selenium); Se - supplementation of $2 \mathrm{mg}$ selenium/kg of dry matter in the form of sodium selenite; $\mathrm{Cu}$ - supplementation of $40 \mathrm{mg}$ copper/ $\mathrm{kg}$ of dry matter in the form of copper sulphate; $\mathrm{Se} \times \mathrm{Cu}$ - supplementation of $2 \mathrm{mg}$ selenium/ $\mathrm{kg}$ of dry matter in the form of sodium selenite and $40 \mathrm{mg}$ copper/kg of dry matter in the form of copper sulphate; SFT - subcutaneous fat thickness; REA - rib eye area. 
sufficient to decrease the activity of the enzyme fatty acid synthase and, consequently, the synthesis of lipids.

The explanation for fat thickness reduction in the experiments of Engle et al. (2000a) and Engle \& Spears (2000) is on the decrease of the performance of animals supplemented with high copper doses. Another explanation would be a possible effect of copper on the ruminal metabolism. According to Engle et al (2000c), copper can serve as a carrier of electrons in reduction processes, so it may interfere in rumen fermentation and consequently in lipid metabolism.

Regarding the treatments withseleniumsupplementation, Lawler et al. (2004) supplemented selenium in cattle and

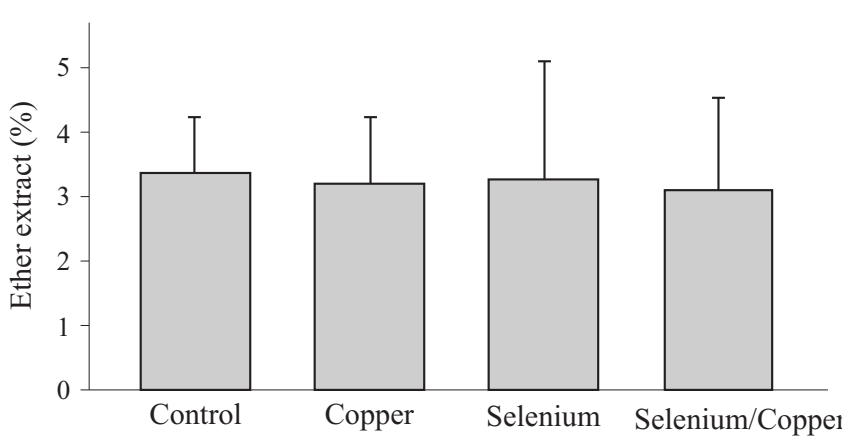

Control - no supplementation.

Copper - $40 \mathrm{mg} / \mathrm{kg}$ of dry matter.

Selenium $-2 \mathrm{mg} / \mathrm{kg}$ of dry matter.

Copper $\times$ selenium $-2 \mathrm{mg}$ selenium $/ \mathrm{kg}$ of dry matter and $\times 40 \mathrm{mg}$ selenium $/ \mathrm{kg}$ of dry matter.

Figure 1 - Ether extract and standard deviation in $\%$ of the original matter on the longissimus dorsi muscle of cattle receiving different diets during the experimental feedlot period. found no change in fat thickness and marbling of meat, like the results of this experiment.

There was no significant difference in the proportion of saturated and unsaturated acids with the supplementations of copper, selenium or selenium $\times$ copper. Compared with control, the treatments had a lower proportion of linoleic and palmitic acids (Table 5; $\mathrm{P} \leq 0.05$ ).

The results showed that the supplementation of copper, selenium or selenium $\times$ copper did not alter the fatty acid profile in meat or its composition of saturated or unsaturated fatty acids. The fatty acid composition in meat is a result of lipogenesis in adipose tissue and also of the dietary lipids and subsequent ruminal biohydrogenation (Berchielli et al., 2006). Some authors found alterations in the fatty acid composition, reduction of saturated fatty acids and increase of unsaturated acids with copper supplementation in the levels of the present study. Engle et al. (2000a), Engle et al. (1999) and Engle \& Spears (2000) found increased fatty acid C18:2 and C18:3 with supplementation of physiological levels of copper.

The explanation of these authors is the decrease of ruminal biohydrogenation promoted by copper and consequent increase in intestinal absorption of unsaturated fatty acids. Engle et al. (2000b) explained that the high potential copper reduction in the rumen may decrease reduction equivalents in the form of NADPH and NADH, interfering with microbial biohydrogenation of unsaturated fatty acids.

In this study, there was no change in the fatty acid profile with the supplementation of copper or selenium. Thus, there was no effect of copper on ruminal biohydrogenation. Engle

Table 5 - Fatty acid profile in the longissimus dorsi muscle of cattle receiving control diet, selenium, copper or selenium $\times$ copper

\begin{tabular}{|c|c|c|c|c|c|c|c|c|c|}
\hline \multirow{2}{*}{ Fatty acid } & \multicolumn{4}{|c|}{ Treatments } & \multirow{2}{*}{ Means } & \multirow{2}{*}{$\mathrm{SE}$} & \multicolumn{3}{|c|}{$P$ values } \\
\hline & $\mathrm{C}$ & $\mathrm{Se}$ & $\mathrm{Cu}$ & $\mathrm{Se} \times \mathrm{Cu}$ & & & $\mathrm{Se}$ & $\mathrm{Cu}$ & $\mathrm{Se} \times \mathrm{Cu}$ \\
\hline \multicolumn{10}{|c|}{$\mathrm{mm}$} \\
\hline Lauric (C 12:0) & 10.90 & 12.97 & 13.27 & 12.61 & 12.47 & 0.91 & 0.612 & 0.714 & 0.482 \\
\hline EPA (C 20:5) & 0.16 & 0.25 & 0.31 & 0.58 & 0.33 & 0.12 & 0.416 & 0.460 & 0.621 \\
\hline Linolenic (C 18:3) & 7.39 & 7.71 & 6.79 & 8.32 & 7.54 & 1.10 & 0.863 & 0.741 & 0.650 \\
\hline DHA (C 22:6) & 1.23 & 0.87 & 0.66 & 0.85 & 0.92 & 0.28 & 0.580 & 0.943 & 0.752 \\
\hline Miristic (C 14:0) & 1.69 & 1.42 & 1.39 & 1.38 & 1.48 & 0.13 & 0.312 & 0.530 & 0.440 \\
\hline Palmitoleic (C 16:1) & 6.68 & 6.25 & 6.10 & 6.53 & 6.40 & 0.32 & 0.740 & 0.302 & 0.273 \\
\hline Linoleic (C 18:2) & 9.81 & 8.17 & 8.25 & 6.70 & 8.61 & 0.55 & 0.041 & 0.051 & 0.031 \\
\hline Palmitic (C 16:0) & 8.90 & 6.80 & 7.03 & 6.15 & 7.22 & 0.51 & 0.033 & 0.042 & 0.040 \\
\hline Oleic (C 18:1) & 34.47 & 32.75 & 36.56 & 37.30 & 35.24 & 0.95 & 0.134 & 0.890 & 0.442 \\
\hline Estearic (C 18:0) & 18.71 & 21.94 & 19.02 & 19.54 & 19.76 & 1.22 & 0.813 & 0.401 & 0.233 \\
\hline Saturated & 39.72 & 43.57 & 41.07 & 39.59 & 40.94 & 1.48 & 0.880 & 0.750 & 0.311 \\
\hline Unsaturated & 60.27 & 56.42 & 58.92 & 60.41 & 59.05 & 1.48 & 0.881 & 0.762 & 0.320 \\
\hline$\omega 3$ & 8.78 & 8.83 & 7.76 & 9.75 & 8.78 & 1.05 & 0.750 & 0.804 & 0.522 \\
\hline$\omega 6$ & 9.81 & 8.17 & 8.25 & 6.70 & 8.23 & 1.10 & 0.812 & 0.331 & 0.454 \\
\hline
\end{tabular}

EPA - eicosapentaenoic acid; DHA - docosahexaenoic acid; SE - standard error; C - control diet (without supplementation of copper and selenium); Se - supplementation of 2 mg selenium $/ \mathrm{kg}$ of dry matter in form of sodium selenite; $\mathrm{Cu}$ - supplementation of $40 \mathrm{mg}$ copper $/ \mathrm{kg}$ of dry matter in form of copper sulphate; Se $\times$ Cu - supplementation of $2 \mathrm{mg}$ selenium $/ \mathrm{kg}$ of dry matter in form of sodium selenite and $40 \mathrm{mg}$ copper $/ \mathrm{kg}$ of dry matter in form of copper sulphate. 
et al. (2000c) studied the effect of copper supplementation and soybean oil on the ruminal biohydrogenation and found interaction between copper supplementation and soybean oil. The authors found reduction of ruminal biohydrogenation only when copper was offered, and increased biohydrogenation when copper and soybean oil were offered in combination.

The source of lipids used in this study was the soy present in extruded soybean. This may have been the reason why no effects were found in the fatty acid composition with the supplementation of copper, selenium or selenium $\times$ copper, since the copper supplementation reduces biohydrogenation, but combined supplementation with soybean oil seems to inhibit this effect.

The decrease in linoleic and palmitic acids with the selenium $\times$ copper treatment compared with control cannot be biologically explained and was not observed in any study in the literature.

\section{Conclusions}

At the levels studied, the dietary supplementation of copper, selenium or selenium $\times$ copper has no influence in the nutritional characteristics of meat, except for the linoleic and palmitic fatty acids.

\section{References}

ASSOCIATION OF OFFICIALANALYTICAL CHEMISTS - AOAC. Official methods of analysis. 16.ed. Arlington: AOAC, 1996.

BERCHIELLI, T.T.; PIRES, A.V.; OLIVEIRA, S.G. Nutrição de ruminantes. Jaboticabal: FUNEP, 2006. v.1, 583p.

BRISOLA, M.L. Efeitos de níveis crescentes de enxofre na dieta de cordeiros submetidos a nível tóxico de selênio. 2000. 89f. Tese (Doutorado em Zootecnia) - Faculdade de Ciências Farmacêuticas/ Universidade de São Paulo, São Paulo.

DEOL, H.S.; HOWELL, J.M; DORLING, P.R. Effect of the ingestion of heliotrope and copper on the concentration of zinc, selenium and molybdenum in the liver of sheep. Journal Comparative Pathology, v.110, p.303-307, 1994.

ENGLE, T.E.; SPEARS, J.W. Dietary copper effects on lipid metabolism. performance and ruminal fermentation in finishing steers. Journal of Animal Science, v.78, p.2352-2458, 2000.

ENGLE, T.E.; SPEARS, J.W. Performance carcass characteristics and lipid metabolism in growing and finishing Simmental steers fed varying concentration of copper. Journal of Animal Science, v.79, p.2920-2925, 2001.

ENGLE, T.E.; SPEARS, J.W.; ARMSTRONG, T.A. Performance and lipid and cholesterol metabolism in finishing steers fed varying concentration of copper. Journal of Animal Science, v.77, p.2446-2451, 1999.
ENGLE, T.E.; SPEARS, J.W.; ARMSTRONG, T.A. et al. Effects of dietary copper source and concentration on carcass characteristics and lipid and cholesterol metabolism in growing and finishing steers. Journal of Animal Science, v.78, p.1053-1059, 2000a.

ENGLE, T.E.; SPEARS, J.W.; EDENS, F.W. Dietary copper effects on lipid metabolism and circulating catecholamine concentration in finishing steers. Journal of Animal Science, v.78, p.2737-2744, 2000b.

ENGLE, T.E.; SPEARS, J.W.; XI, L. et al. Effects of dietary soybean oil and dietary copper on ruminal and tissue lipid metabolism in finishing steers. Journal of Animal Science, v.78, p.2713-2721, 2000c.

FOX, D.G.; SNIFFEN, C.J.; O'CONNOR, J.D. et al. A net carbohydrate and protein system for evaluating cattle diets. III. Cattle requirements and diets adequacy. Journal of Animal Science, v.70, p.3578-3596, 1992.

HERDT, T.H.; RUMBEIHA, W.; BRASELTON, W.E. The use of blood analyses to evaluate mineral status in livestock. Vet. Clin North America: Food Anim Pract., v.16, p.423-444, 2000.

KONJUFCA V.H.; PESTI, G.M.; BAKALLI, R.I. Modulation of cholesterol levels in broiler meat by garlic and copper. Poultry Science, v.76, p.1264-1271, 1997.

LAWLER, T.L.; TAYLOR, J.B.; FINELY, J.W. et al. Effect of supranutritional and organically bond selenium on performance carcass characteristics, and selenium distribution in fishing beef steers. Journal of Animal Science, v. 82, p. 1488-1493, 2004

MAHAN, D.C.; CLINE, T.R.; RICHERT, T. Effects of dietary levels of selenium-enriched yeast and sodium selenite as selenium sources fed to growing-finishing pigs on performance, tissue selenium, serum glutathione peroxidase activity, carcass characteristics, and loin quality. Journal of Animal Science, v.77, p.2172-2179, 1999.

McCHOWELL, J.; GAWTHORNE, J.M. Cooper in animals and man. Boca Raton: CRC Press, 1985. v.1, p.101-119.

McDOWELL, L.R. Minerals in animal and human nutrition. New York: Academic Press, 1992. 524p.

NATIONAL RESEARCH COUNCIL - NRC. Nutrient requirements of beef cattle. Washington: National Academy Press, 2000. 248p.

NATIONAL RESEARCH COUNCIL - NRC. Mineral tolerance of animals. 2.ed, Washington: National Academy Press, 2005. 510p.

O'DELL, B.L.; SUNDE, R.A. Handbook of nutritionally essential mineral elements. New York: Marcel Decker, 1997. 692p.

OLSON, O.E.; PALMER, I.S.; CARY, E.E. Modification of the official fluorimetric method for selenium in plants. Journal Association of Agricultural Chemistry, v.58, n.1, p.117-121, 1975.

PEREZ, J.R.O.; BRESSAN, M.C.; BRAGAGNOLO, N. Efeito do peso ao abate de cordeiros Santa Inês e Bergamácia sobre o perfil de ácidos graxos, colesterol e propriedades químicas. Ciência Tecnologia Alimentos, v.22, p.11-18, 2002.

UNDERWOOD, E.J.; SUTTLE, N.F. The mineral nutrition of livestock. 3.ed. New York: CABI, 1999. 624p.

VALK, E.E.; HORSTRA, G. Relationship between vitamin E requirement and polyunsaturated fatty acid intake in man: a review. International Journal for Vitamin and Nutrition Research, v.70, p.30-41, 2000.

VAN RYSSEN, J.B.J.; VAN MALSEN, P.S.M.; HARTMANN, F. Contribution of dietary sulphur to the interaction between selenium and copper in sheep. Journal of Agricultural Science, v.130, p.107-114, 1998.

WARD, J.D.; SPEARS, J.W. Long-term effects of consumption of low-copper diets with or without supplemental molybdenum on copper status, performance, and carcass characteristics of cattle. Journal of Animal Science, v.75, p.3057-3065, 1997. 